\title{
Update on leukotriene receptor antagonists in preschool children wheezing disorders
}

\author{
Silvia Montella, Marco Maglione, Sara De Stefano, Angelo Manna, Angela Di Giorgio and Francesca Santamaria*
}

\begin{abstract}
Asthma is the most common chronic disease in young children. About $40 \%$ of all preschool children regularly wheeze during common cold infections. The heterogeneity of wheezing phenotypes early in life and various anatomical and emotional factors unique to young children present significant challenges in the clinical management of this problem. Anti-inflammatory therapy, mainly consisting of inhaled corticosteroids (ICS), is the cornerstone of asthma management. Since Leukotrienes (LTS) are chemical mediators of airway inflammation in asthma, the leukotriene receptor antagonists (LTRAs) are traditionally used as potent anti-inflammatory drugs in the long-term treatment of asthma in adults, adolescents, and school-age children. In particular, montelukast decreases airway inflammation, and has also a bronchoprotective effect. The main guidelines on asthma management have confirmed the clinical utility of LTRAs in children older than five years. In the present review we describe the most recent advances on the use of LTRAs in the treatment of preschool wheezing disorders. LTRAs are effective in young children with virus-induced wheeze and with multiple-trigger disease. Conflicting data do not allow to reach definitive conclusions on LTRAs efficacy in bronchiolitis or post-bronchiolitis wheeze, and in acute asthma. The excellent safety profile of montelukast and the possibility of oral administration, that entails better compliance from young children, represent the main strengths of its use in preschool children. Montelukast is a valid alternative to ICS especially in poorly compliant preschool children, or in subjects who show adverse effects related to long-term steroid therapy.
\end{abstract}

Keywords: Leukotriene receptor antagonists, Asthma, Preschool children, Wheezing, Bronchiolitis

\section{Introduction}

Asthma is the most common chronic disease of the airways in young children [1]. About $40 \%$ of all preschool children regularly wheeze during common cold infections. Although about two-thirds of these children lose their symptoms after the age of six years, the disease places a considerable burden on the child, the child's family, and society because of the high prevalence and lack of good treatment control [2]. Moreover, the heterogeneity of wheezing phenotypes early in life presents significant challenges in the clinical management of this problem.

Anti-inflammatory therapy is the cornerstone of asthma management. Studies of the efficacy of inhaled corticosteroids (ICS) in preschool children have given conflicting results. Some studies show that ICS are effective in improving symptoms and lung function [3-8],

\footnotetext{
* Correspondence: santamar@unina.it

Department of Pediatrics, Federico II University, Via Sergio Pansini, 5, Naples 80131, Italy
}

(C) 2012 Montella et al.; licensee BioMed Central Ltd. This is an Open Access article distributed under the terms of the Creative Commons Attribution License (http://creativecommons.org/licenses/by/2.0), which permits unrestricted use, distribution, and reproduction in any medium, provided the original work is properly cited.

although safety data are worrisome [9], while others find no effect at all on the prevention of progression to established asthma [10-12]. The most plausible explanation for these differences is that there is no single wheezing phenotype in young children, since the disease may be provoked by respiratory viruses, allergens, exercise and exposure to smoke or other pollutants [13]. In addition to this, there are various anatomical, physiological and emotional factors unique to young children, especially infants, that result in significant difficulties and challenges to inhalation therapy [14]. All these troubles can be easily overcome by oral drug administration.

The leukotriene receptor antagonists (LTRAs) are traditionally used as anti-inflammatory drugs in the long-term treatment of asthma in adults, adolescents, and school-age children [15-17]. This review summarizes the most recent development on the use of LTRAs in the treatment of preschool wheezing disorders. 


\section{Leukotrienes mechanism of action and biological effects}

Leukotrienes (LTs) are chemical mediators of airway inflammation in asthma, produced from membrane phospholipids via the 5-lipoxygenase pathway of the arachidonic acid cascade (Figure 1) [18]. After activation by mechanical, chemical, or physical stimuli, cytosolic phospholipase A2 translocates to the membrane to liberate membrane-bound arachidonic acid. Free arachidonic acid either can be converted by the cyclooxygenase pathway to form prostanoids (prostaglandins, prostacyclin and thromboxane) or, alternatively, can follow the 5lipoxygenase pathway to form LTs. In combination with the 5-lipoxygenase activating protein, the 5-lipoxygenase enzyme acts on arachidonic acid to form the 5hydroperoxyeicosatetraenoic acid, which is then converted to the nonpeptide leukotriene $\mathrm{LTA}_{4}$. $\mathrm{LTA}_{4}$ can then be converted to the cysteinyl leukotrienes (CysLTs) $\mathrm{LTC}_{4}, \mathrm{LTD}_{4}$ and $\mathrm{LTE}_{4}$ which provoke bronchial and vascular constriction and therefore play a central role in the pathophysiology of asthma [18].

The CysLTs are synthesized by several cells, including neutrophils, eosinophils, mast cells, alveolar macrophages, epithelial cells and vascular endothelial cells, which are present or recruited to the lung when airways inflammation occurs. The production of LTs by these cells depends on the selective expression of the enzymes involved in the metabolic pathway. $\mathrm{LTA}_{4}$ may be directly released into the extracellular environment and there be metabolized by other cells (transcellular biosynthesis). This pathway results in $\mathrm{LTB}_{4}$ production by bronchial epithelial cells, despite 5-lipoxygenase enzyme is absent [18].

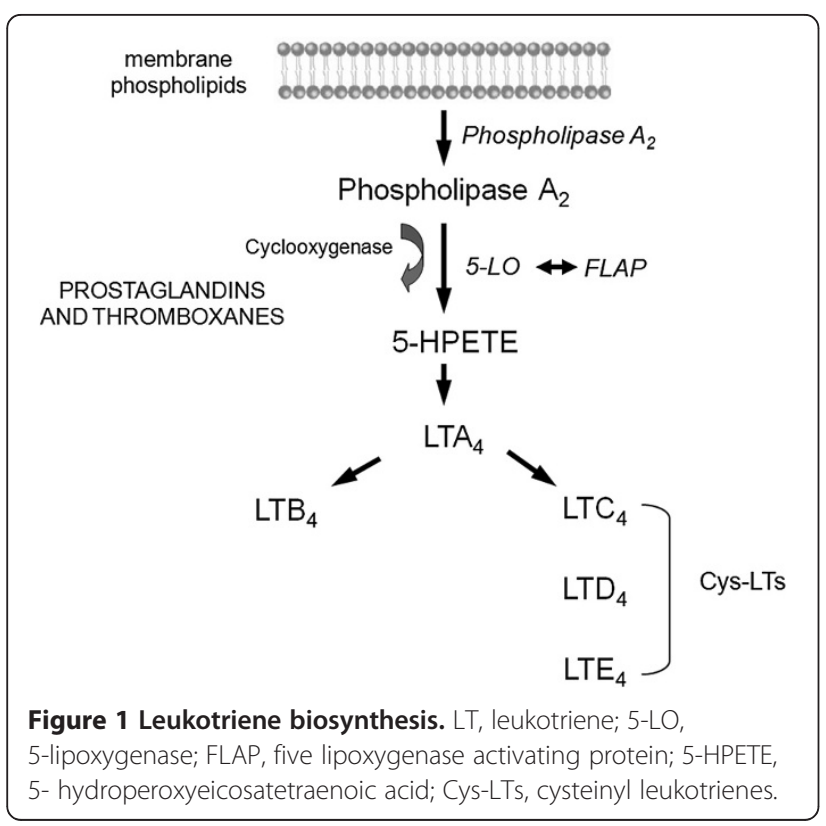

Due to its activity in cellular recruitment and activation, $\mathrm{LTB}_{4}$ is an important proinflammatory mediator, also involved in the stimulation of the interleukin biosynthesis by $\mathrm{T}$ lymphocytes and monocytes, with consequent increase in vascular permeability and mucous production [19]. Conversely, CysLTs act on the smooth muscle cells, inducing a constrictive effect much stronger than that determined by methacoline or histamine. Furthermore, they are potent in eliciting bronchoconstriction, mucous production and vasodilatation, and may enhance the airways hyperresponsiveness that is characteristic of the asthmatic disease [20].

CysLTs receptor antagonists bind the $\mathrm{LTD}_{4}$ receptor and prevent the interaction between the receptor and its physiological ligands [21]. Due to this receptor obstruction, LTs cannot activate the signal transduction that leads to bronchoconstriction. Among LTRAs, zafirlukast, pranlukast and montelukast have been approved in several countries for asthma treatment of adults and children. Montelukast (MK-0476), is the most specific and powerful LTs receptor antagonist, and is the only LTRA that has been approved for preschool children use in several countries including Italy. In addition to its use as controller drug in allergic and viral-induced asthma, it decreases also bronchial hyperreactivity and prevents bronchial obstruction induced by physical activity at preschool and school age [22,23].

CysLTs production is greatly increased in allergen- or exercise-induced asthma, particularly during exacerbations [24]. Children with steroid-naïve mild persistent, severe persistent and unstable asthma have high levels of exhaled CysLTs [25]. Moreover, CysLTs and $\mathrm{LTB}_{4}$ are significantly increased also in children with mild and moderate to persistent asthma treated with low or high doses of inhaled ICS [26].

CysLTs activate type 1 and type 2 leukotriene receptors (CysLT1 and CysLT2) on cell membranes [27]. CysLT1 receptors are localized primarily on pulmonary smooth muscle cells. Activation of these receptors by CysLT leads to decreased activity of respiratory cilia, increased mucous secretion, increased venopermeability and promotion of eosinophils into the airways [28]. This, in turn, induces airway smooth-muscle proliferation and may play a role in the development of airway remodeling. Moreover, CysLTs are the most potent bronchoconstrictive agents discovered, being 100-1000 times more potent than histamines [29].

\section{Scientific evidences about LTRAs in preschool children}

Monotherapy with montelukast

Only few short- or long-term randomized controlled trials (RCTs) with LTRAs have been conducted in preschool age. 


\section{Short-term monotherapy}

A study of asthmatic children aged 2-5 years demonstrated that administration of $5 \mathrm{mg} /$ die of montelukast for two days protects against cold air-induced bronchial hyperreactivity [30]. This finding was later confirmed in patients who showed a significant decrease in methacoline-induced bronchial reactivity after a fourweeks treatment with montelukast [22].

In atopic children with asthma, monotherapy with montelukast for 28 days was reported to be effective for reducing airway resistance and bronchial inflammation [31], and for improving lung function and symptoms score [32]. Finally, an Australian RCT conducted in children with mild intermittent asthma, demonstrated that a short course of montelukast, introduced at the first signs of an asthma episode, resulted in a significant reduction in acute health care resource utilization, symptoms, time off from school, and parental time off from work [33]. However, no significant effect on hospitalization rate, duration of symptoms, use of bronchodilators and systemic steroids was found, and finally, the number of symptom-free days, one of the primary outcomes of therapeutic efficacy, was not considered by the authors.

\section{Long-term monotherapy}

In 2001, a large multicenter, double-blind, international study on 689 preschool children with multi-trigger wheezing and persistent symptoms showed that daily montelukast given over three months is associated with more symptom-free days (34\% versus $28 \%$ in the placebo group) [34]. In another study, Davies and coworkers found that patients aged 2 to 5 years with mild to moderate persistent asthma receiving long-term therapy with montelukast had similar rates of asthma-related health care resource utilization compared with those receiving usual care with cromolyn or ICS [35]. In 2005 the PREVIA study (PREvention of Viral Induced Asthma) showed that a 1-year course of montelukast in children with virus-induced asthma significantly reduces asthma exacerbations and the use of rescue medications [36]. Despite several criticisms, particularly regarding the number of symptom-free days that was not significantly different in the two groups (76\% versus $73 \%$ in the placebo group, $\mathrm{p}=0.059$ ), and the use of systemic steroids that was not significantly reduced after treatment [37], the PREVIA study remains one of the few RCTs in preschool children with mild intermittent asthma that proves that prolonged treatment with montelukast reduces the consumption of ICS at a high rate (39.8\%).

Studies that compared either short- or long-term treatment with LTRAs given as monotherapy to other antiasthma controller drugs in preschool children showed that montelukast is as effective as ICS. Szefler and coworkers evaluated the efficacy of montelukast versus budesonide in 349 children, mostly at preschool age, with mild persistent asthma, and found no differences between the two groups as far as drug tolerability, time to first additional anti-asthma medications and time to first severe exacerbation over a 52 weeks-study period [38]. Another small RCT assessed the efficacy of montelukast or fluticasone given as monotherapy versus placebo for three months [39]. Both drugs decreased asthma-like symptoms and improved the daily symptoms score, even though fluticasone appeared more effective than placebo. Nevertheless, the symptoms score also improved in the placebo group, suggesting that asthma-like symptoms, that are commonly associated with respiratory virus infections in preschool age, may spontaneously improve. Unfortunately, this study was conducted on a limited population and therefore the statistical power might be questioned [39].

In addition, the results of a RCT of preschool children, most of whom had positive asthma predictive indices, showed that the episodic use of either budesonide or montelukast for 7 days during an asthma exacerbation does not increase the proportion of symptom-free days or decrease oral corticosteroids and health care resources use [40]. Nevertheless, both drugs appeared effective in decreasing the severity of symptoms, particularly in cases with positive asthma predictive indices or with more severe clinical manifestations.

Finally, a retrospective analysis of 2034 asthmatic children treated with montelukast and fluticasone as monotherapy, showed that both drugs decrease rescue medications use and hospital visits [41]. In particular, in children aged 2 to 5 years, montelukast was associated to less emergency visits compared to subjects aged 6 to 14 years. This finding was taken by authors to conclude that the beneficial effects of LTRAs may be mainly observed in preschool children.

All the above findings indicate that LTRAs may be beneficial in preschool wheeze. However, since only two RCTs compared montelukast to ICS $[39,40]$, more comparative studies of preschool children treated with LTRAs versus ICS should hopefully be promoted $[42,43]$. Likewise, the intermittent use of montelukast has been evaluated only in mild, or moderate-to severe intermittent wheeze $[33,40]$, and this modality of treatment might be extended to children with severe recurrent or persistent symptoms.

\section{Combined therapy (montelukast plus inhaled steroids)}

Combined therapy with montelukast and ICS in preschool children has been poorly investigated. One study of 194 children (22\% aged 2 to 5 years) showed that montelukast added to the usual treatment with ICS reduced the risk of worsening asthma symptoms and unscheduled physician visits during the annual September 
asthma epidemic [44]. Another study had previously found that montelukast more effectively reduces acute asthma episodes if started before the viral season, when the exacerbation rate is higher [36]. Very few evidences support the effectiveness of montelukast combined to ICS as long-term asthma treatment or during an acute exacerbation $[42,45]$.

\section{Montelukast and bronchiolitis}

CysLTs are increased in respiratory secretions from infants with acute viral bronchiolitis and their levels remain significantly high at short-term follow-up, suggesting a possible role of CysLTs in the pathogenesis of the disease [46]. However, the results of the published RCTs are controversial. Amirav and coworkers demonstrated that montelukast given to infants with a first episode of bronchiolitis from the hospital admission until discharge did not reduce the length of stay, or the cytokine levels in nasal lavage fluid, nor improved the clinical severity scores [47]. Likewise, no significant benefit of montelukast administered both at 4 and 20 weeks after the onset of respiratory symptoms was shown in a large study of infants with post respiratory syncytial virus (RSV) bronchiolitis [48]. A small RCT confirmed this result, showing that montelukast given for three months after hospital admission for RSV bronchiolitis did not reduce the respiratory symptoms during both the treatment and the follow up periods [49]. All these findings appear conflicting with the conclusions of one of the first studies of RSV bronchiolitis that showed that montelukast results in significant improvement of symptoms score and in decrease of nighttime symptoms and daytime cough [50]. Finally, a recent RCT demonstrated that montelukast given for 3 months reduces eosinophilic degranulation $(\mathrm{p}<0.01)$ and decreases the number of recurrent wheezing episodes $(\mathrm{p}=0.039)$ in children 6 to 24 monthsold with post-RSV bronchiolitis [51].

These conflicting results do not allow to reach definitive conclusions, and highlight the need for further studies on children with recurrent wheeze associated with RSV bronchiolitis.

\section{Acute asthma}

The use of montelukast in acute asthma has received very poor attention. High concentrations of CysLTs have been found in urine patients with acute asthma exacerbations [52], and LTRAs administration could thus improve symptoms control during asthma attacks.

There are no studies on oral montelukast use in children under 1 year of life with acute wheezing. A RCT of 51 children aged 2 to 5 years with mild to moderate asthma evaluated the use of montelukast combined with albuterol at the first symptoms of an acute exacerbation [52]. When compared to patients treated with albuterol alone, subjects who received montelukast showed lower severity of symptoms 90 minutes after the onset of the exacerbation. This difference lasted up to four hours after the first symptoms, and a lower need for oral steroids was also reported. Treatment with montelukast initiated in children with intermittent asthma at the onset of upper respiratory infections (URI) or acute asthma, reduced symptoms $(\mathrm{p}=0.049)$ and days off from school $(p<0.0001)$, but did not affect the use of asthma medications $(p=0.25)$ [33]. An additional RCT demonstrated that in moderate-to-severe intermittent wheezing a 7-days course of montelukast does not decrease oral corticosteroid use over a 12-month period, when compared with placebo or budesonide inhalation in addition to albuterol $(p=0.15)$ [40]. Despite the association between URI and onset of asthma has been repeatedly documented [1,33,36,37], a recent RCT of 300 preschool children with URI showed that a 12-week treatment with montelukast did not reduce the incidence of URI [53].

Given the controversial data available until now, we believe that further studies are urgently needed to support the treatment with LTRAs of preschool children with acute wheezing, especially in infants younger than one year.

Main results from all the studies conducted in children with preschool wheezing disorders treated with montelukast, alone or combined with ICS, are summarized in Table 1 and Table 2.

\section{Adverse events}

LTRAs are generally well tolerated. Most of the adverse events described are mild (headache, gastrointestinal disorders, pharyngitis, cutaneous rash and reversible alterations in levels of serum transaminase) and do not significantly differ from those described in subjects receiving placebo [54].

Among respiratory medications used in the Italian pediatric population, montelukast is seldom prescribed as off-label drug, and its use is overall increasing [55]. This trend reflects recommendations from asthma guidelines, that support beneficial effects of LTRAs also in children aged less than 6 years [29]. A recent review on safety and tolerability of montelukast in children with both episodic (viral) and persistent multi-trigger wheeze concluded that its safety profile is comparable to that of placebo [54]. Adverse events most frequently reported include upper respiratory tract infections, worsening of wheeze, fever and self-limited cough, particularly in preschool children.

Risk for hepatic toxicity appears lower for montelukast than other molecules of the same group, and no increased risk of hypertransaminasemia during the treatment has been reported [45]. A large study on 1.948.297 children aged less than 5 years reported 3698 cases of 
Table 1 Studies of preschool wheezing children treated with montelukast alone or with inhaled corticosteroids (ICS)

\begin{tabular}{|c|c|c|c|}
\hline & Author & Pros & Cons \\
\hline & Bisgaard [30] & Protection against cold air-induced reactivity & \\
\hline & Hakim [22] & Reduced methacoline-induced reactivity & \\
\hline Wheezing (short-term & Straub [31] & Reduced airway resistance and exhaled nitric oxide & \\
\hline \multirow[t]{5}{*}{ montelukast monotherapy) } & Straub [32] & Improved lung function and symptom score & \\
\hline & Robertson [33] & $\begin{array}{l}\text { Reduced healthcare resource use, symptoms, } \\
\text { time-off school/parent work }\end{array}$ & $\begin{array}{l}\text { No effect on hospitalization rate, } \\
\text { symptoms duration, } \beta_{2} \text { or steroids use }\end{array}$ \\
\hline & Szefler [38] & No difference versus budesonide for & Higher rates of exacerbations \\
\hline & & - time to 1 st additional asthma drug at 12 weeks & \\
\hline & & - time to 1st attack requiring oral steroid & \\
\hline Wheezing (long-term & Kooi [39] & Montelukast versus fluticasone or placebo & \\
\hline montelukast & & In all groups & In all groups: no differences \\
\hline \multirow[t]{9}{*}{ monotherapy) } & & - Improved symptoms score & in lung function \\
\hline & & - Reduced blood eosinophils & \\
\hline & Allen-Ramey [41] & Emergency visits fewer versus fluticasone & $\begin{array}{l}\text { No differences in hospitalizations or } \\
\text { rescue drugs }\end{array}$ \\
\hline & Davies [35] & $\begin{array}{l}\text { Similar rates of healthcare resource of } \\
\text { cromolyn or ICS }\end{array}$ & \\
\hline & Bisgaard [36] & Lower & \\
\hline & & - rate of asthma exacerbations & \\
\hline & & - median time to first exacerbation & \\
\hline & & - rate of ICS courses & \\
\hline & Bacharier [40] & & $\begin{array}{l}\text { No difference in symptom free-days, } \\
\text { oral steroid, healthcare resource use }\end{array}$ \\
\hline Wheezing & Johnston & Reduced risk of : & \\
\hline \multirow[t]{2}{*}{ (montelukast + ICS) } & [44] & - worsened asthma symptoms & \\
\hline & & - unscheduled physician visits & \\
\hline
\end{tabular}

References are in parenthesis.

montelukast overdosing, and authors concluded that no risk of relevant adverse events is associated to ingestion of more than $536 \mathrm{mg}$ or $34 \mathrm{mg} / \mathrm{kg}$ [56]. No toxic effects have been described in two asthmatic children aged 2 and 5 years who were managed at home and in an emergency department, respectively, after unintentional poisoning [57]. This report concludes that montelukast does not entail toxic effects for doses below $4.5 \mathrm{mg} / \mathrm{kg}$.

Churg-Strauss syndrome (CSS) is a rare but lifethreatening granulomatous and eosinophilic vasculitis that occurs preferentially in school-age, adolescents and adults with pre-existing asthma [58]. Since the introduction of LTRAs, several studies reported the development of this condition after the onset of the treatment, particularly with zafirlukast [59], but CSS has never been described in preschool children.

The neuropsychiatric manifestations reported in old children during montelukast treatment have never been observed in preschool age. Nevertheless, even in adults and adolescents, the results of the clinical trials do not provide substantial evidence to support a causal association between montelukast therapy and such disorders [60].

All the above reported data support a good safety profile of montelukast and encourage its use in the clinical practice. Future long-term studies in preschool children will provide further information regarding potential adverse events of LTRAs use in this age range.

\section{From asthma guidelines to recommendations}

The main guidelines on asthma management (Global Initiative for Asthma, GINA; British Thoracic Society, BTS; National Institute of Health, NIH) have confirmed the clinical utility of LTRAs in children older than five years [15-17]. In school age children and adolescents, LTRAs are recommended in mild persistent asthma as second-line therapy in alternative to ICS, or in moderate persistent asthma as add-on to ICS, in alternative to ICS alone [17] with beneficial effects on asthma control and on the number of exacerbations [16,61]. Moreover, regular treatment with LTRAs effectively protects against 
Table 2 Studies of children with bronchiolitis and post-bronchiolitis, and acute asthma treated with montelukast

\begin{tabular}{|c|c|c|c|}
\hline & Author & Pros & Cons \\
\hline & & & No difference: \\
\hline & & & - in length of stay \\
\hline & Amirav [47] & & - in clinical severity score \\
\hline & & & - in cytokine levels in nasal lavage fluid \\
\hline & Bisgaard [48] & & $\begin{array}{l}\text { No differences in percentage } \\
\text { symptom-free days }\end{array}$ \\
\hline & & & No differences: \\
\hline \multirow[t]{9}{*}{$\begin{array}{l}\text { Bronchiolitis and } \\
\text { post bronchiolitis }\end{array}$} & Proesmans [49] & & $\begin{array}{l}\text { - of symptoms and disease-free } \\
\text { days and nights }\end{array}$ \\
\hline & & & - of $n^{\circ}$ of exacerbations \\
\hline & & & $\begin{array}{l}\text { - of } \mathrm{n}^{\circ} \text { of unscheduled visits and } \\
\text { need of inhaled steroids }\end{array}$ \\
\hline & & $\begin{array}{l}\text { Higher percentage of symptom-free } \\
\text { days and nights }\end{array}$ & \\
\hline & Bisgaard [50] & Reduced daytime cough & \\
\hline & & Decreased exacerbations versus placebo & \\
\hline & $\operatorname{Kim}[51]$ & $\begin{array}{l}\text { Reduced serum eosinophil-derived } \\
\text { neurotoxin levels compared with initial levels }\end{array}$ & \\
\hline & & $\begin{array}{l}\text { Decreased cumulative recurrent wheezing } \\
\text { episodes at } 12 \text { months versus placebo }\end{array}$ & \\
\hline & Harmanci [52] & Reduced oral steroids need & \\
\hline \multirow[t]{3}{*}{ Acute asthma } & & $\begin{array}{l}\text { Decreased lung index scores } \\
\text { and respiratory rate versus placebo }\end{array}$ & Hospitalization rates not significantly different \\
\hline & Robertson [33] & $\begin{array}{l}\text { Reduced healthcare resource use, } \\
\text { symptoms, time-off school/parent work }\end{array}$ & $\begin{array}{l}\text { No effect on hospitalization rate, } \\
\text { symptoms duration, } \beta_{2} \text { or steroids use }\end{array}$ \\
\hline & Bacharier [40] & & $\begin{array}{l}\text { No difference in symptom free-days, oral steroid, } \\
\text { healthcare resource use }\end{array}$ \\
\hline
\end{tabular}

References are in parenthesis.

exercise-induced bronchoconstriction, with no tolerance to the bronchoprotective effect [23].

In children younger than 5 years of age, only very few RCTs have been conducted, and therefore the recommendations made by official guidelines on LTRAs treatment mainly derive from studies conducted in older children. In the GINA guideline LTRAs are suggested especially because of their efficacy in reducing virusinduced exacerbations, which are extremely frequent at preschool age [15]. According to the BTS document, LTRAs may be administered in alternative to ICS, or as an add-on therapy in children who do not fully respond to ICS [16]. Finally, the NIH guideline recommends LTRAs to young children to overcome the difficulties due to the use of inhalator devices, or when compliance is poor [17].

In 2008 two relevant documents have provided indications for asthma management in preschool age $[13,62]$. First, the PRACTALL ("PRACTicing ALLergology") consensus report concluded that LTRAs are effective as short- or long-term therapy for controlling virus-induced asthma exacerbations in children under 2 years of age, and may be used alone in alternative to ICS in children 3 to 5 years old with intermittent or mild persistent asthma, [13]. Second, a Task Force committed by the European Respiratory Society (ERS) identified two different wheezing phenotypes: a) episodic (viral) wheezing, characterized by intermittent wheeze and no symptoms between episodes; and b) multiple-trigger wheeze, induced by several stimuli including exercise and allergens, in children who wheeze both during and outside discrete episodes [62]. Indeed, this classification has raised several concerns. The identification of the wheezing phenotype is generally based on symptoms reported by parents, and a wide overlapping of clinical symptoms and signs between the two categories may occur [63]. Moreover, preschool wheezing phenotypes can change over time, entailing relevant modifications in previously established treatment decisions [64]. As far as LTRAs, the ERS document concluded that a trial with montelukast may be considered in both multi-trigger and viral wheeze, but that further 
Table 3 Keypoints in the use of montelukast in preschool children with wheezing disorders

\begin{tabular}{|c|c|}
\hline Evidences & Controversies \\
\hline $\begin{array}{l}\text { Effectiveness in episodic } \\
\text { (viral) wheeze }\end{array}$ & $\begin{array}{l}\text { Effectiveness of intermittent use in } \\
\text { severe recurrent wheeze }\end{array}$ \\
\hline $\begin{array}{l}\text { Effectiveness in } \\
\text { multi-trigger wheeze }\end{array}$ & $\begin{array}{l}\text { Effectiveness of combined therapy } \\
\text { with inhaled steroids in wheezing children }\end{array}$ \\
\hline $\begin{array}{l}\text { Reduction of } \\
\text { airway inflammation }\end{array}$ & $\begin{array}{l}\text { Effectiveness in severe post-RSV } \\
\text { bronchiolitis wheeze }\end{array}$ \\
\hline Excellent safety profile & Effectiveness in acute exacerbation \\
\hline $\begin{array}{l}\text { Good compliance due to } \\
\text { oral single administration }\end{array}$ & $\begin{array}{l}\text { Selection criteria of subjects with } \\
\text { wheezing to treat with monotherapy or } \\
\text { combined therapyv with inhaled steroids }\end{array}$ \\
\hline
\end{tabular}

studies are needed to strengthen these recommendations [62].

Important keypoints about montelukast in preschool wheezing are summarized in Table 3 . They include both evidences definitively supporting its use in the clinical practice, and uncertainties that still limit its prescription.

\section{Conclusions}

The optimal therapeutic strategy for wheezing disorders in early life remains elusive. The pathophysiology is still poorly understood, and likely includes factors other than airway inflammation [65]. Future research in this area should hopefully incorporate consideration in particular of the heterogeneous nature of asthma in preschool children.

Since current recommendations on the use of montelukast, both alone or combined with ICS, derive from evidences in older children, further research is urgently needed to confirm the effectiveness of LTRAs in young wheezing children. Based on the current body of evidence, there is rationale for further investigation of these management strategies, including direct comparisons between ICS and LTRAs, as well as the role of long-acting beta-agonists, potentially targeting the subpopulations of early wheezers who are at highest risk for the persistence of asthma symptoms.

An additional important keypoint is represented by the identification of subjects who wheeze and may benefit from montelukast alone, or from combined therapy. In particular, combined therapy with ICS plus LTRAs might result effective in achieving symptom control and in decreasing health care resource utilization [66]. The intermittent use of montelukast for treating in particular preschool children with severe recurrent wheeze should be more investigated. Finally, further studies should be promoted to confirm that montelukast is effective in preschool acute asthma [53] and to clarify the controversial data published on LTRAs effects in post-RSV bronchiolitis $[37,48,49]$.
Montelukast is a safe drug, with a prominent antiinflammatory activity to the airways [31], and also a strong bronchoprotective effect [30]. Montelukast administered as inhaled drug has been recently reported to provide a significant bronchodilation compared to placebo, in adolescents and adults with chronic asthma [67], but no studies are available in school-age or preschool children.

The excellent safety profile of montelukast, and the possibility of oral administration, which entails better compliance from young children, represent the main strengths of its use in preschool children. Therefore, montelukast represents a valid alternative to ICS in poorly compliant children, or in subjects who show adverse effects related to long-term steroid therapy.

\section{Abbreviations}

ICS: Inhaled corticosteroids; LTRAs: LTs, Leukotrienes; LTRAs: Leukotriene receptor antagonists; CysLTs: Cysteinyl leukotrienes; GINA: Global Initiative for Asthma; BTS: British Thoracic Society; NIH: National Institute of Health; RCT: Randomized controlled clinical trial; ERS: European Respiratory Society; RSV: Respiratory syncytial virus.

\section{Competing interests}

All authors declare that they have no significant competing financial, professional or personal interests that might have influenced the performance or presentation of the work described in this manuscript.

\section{Authors' contributions}

SM has been involved in drafting the manuscript and revising it critically for important intellectual content; MM has been involved in drafting the manuscript; SDS has been involved in drafting the manuscript; AM has made substantial contributions to acquisition, analysis and interpretation of data; ADG has made substantial contributions to acquisition, analysis and interpretation of data; FS has been involved in drafting the manuscript, revising it critically for important intellectual content and has given final approval of the version to be published. All authors read and approved the final manuscript.

Received: 13 February 2012 Accepted: 4 June 2012

Published: 26 June 2012

\section{References}

1. Martinez FD, Wright AL, Taussig LM, Holberg CJ, Halonen M, Morgan WJ: Asthma and wheezing in the first six years of life. N Engl J Med 1995, 332:133-138.

2. Stevens CA, Turner D, Kuehni CE, Couriel JM, Silverman M: The economic impact of preschool asthma and wheeze. Eur Respir J 2003, 21:1000-1006.

3. Zielen S, Rose MA, Bez C, Jarisch A, Reichenbach J, Hofmann D: Effectiveness of budesonide nebulising suspension compared to disodium cromoglycate in early childhood asthma. Curr Med Res Opin 2006, 22:367-373.

4. de Blic J, Delacourt C, Le Bourgeois M, Mahut B, Ostinelli J, Caswell C, Scheinmann P: Efficacy of nebulized budesonide in treatment of severe infantile asthma: a double-blind study. J Allergy Clin Immunol 1996, 98:14-20.

5. Ilangovan P, Pedersen S, Godfrey S, Nikander K, Noviski N, Warner JO: Treatment of severe steroid dependent preschool asthma with nebulised budesonide suspension. Arch Dis Child 1993, 68:356-359.

6. Papi A, Nicolini G, Boner AL, Baraldi E, Cutrera R, Fabbri LM, Rossi GA: Short term efficacy of nebulized beclomethasone in mild-to-moderate wheezing episodes in pre-school children. Ital J Pediatr 2011, 37:39.

7. Zeiger RS, Mauger D, Bacharier LB, Guilbert TW, Martinez FD, Lemanske RF Jr, Strunk RC, Covar R, Szefler SJ, Boehmer S, Jackson DJ, Sorkness CA, Gern JE, Kelly HW, Friedman NJ, Mellon MH, Schatz M, Morgan WJ, Chinchilli VM, Raissy HH, Bade E, Malka-Rais J, Beigelman A, Taussig LM, CARE Network of the National Heart, Lung, and Blood Institute: Daily or intermittent 
budesonide in preschool children with recurrent wheezing. N Engl J Med 2011, 365:1990-2001.

8. Baraldi E, Rossi GA, Boner AL: Beclomethasone and Salbutamol Treatment (BEST) for Children Study Group (NCT00497523). Budesonide in preschool-age children with recurrent wheezing. N Engl J Med 2012, 366:570-571.

9. Ducharme FM, Zemek RL, Schuh S: Oral corticosteroids in children with wheezing. N Engl J Med 2009, 360:1674.

10. Bisgaard H, Hermansen MN, Loland L, Halkjaer LB, Buchvald F: Intermittent inhaled corticosteroids in infants with episodic wheezing. $N$ Engl J Med 2006, 354:1998-2005

11. Guilbert TW, Morgan WJ, Zeiger RS, Mauger DT, Boehmer SJ, Szefler SJ, Bacharier LB, Lemanske RF Jr, Strunk RC, Allen DB, Bloomberg GR, Heldt G, Krawiec M, Larsen G, Liu AH, Chinchilli VM, Sorkness CA, Taussig LM, Martinez FD: Long-term inhaled corticosteroids in preschool children at high risk for asthma. N Engl J Med 2006, 354:1985-1997.

12. Murray CS, Woodcock A, Langley SJ, Morris J, Custovic A, IFWIN study team: Secondary prevention of asthma by the use of Inhaled Fluticasone propionate in Wheezy INfants (IFWIN): double-blind, randomised, controlled study. Lancet 2006, 368:754-762.

13. Bacharier LB, Boner A, Carlsen KH, Eigenmann PA, Frischer T, Götz M, Helms PJ, Hunt J, Liu A, Papadopoulos N, Platts-Mills T, Pohunek P, Simons FE, Valovirta E, Wahn U, Wildhaber J, European Pediatric Asthma Group: Diagnosis and treatment of asthma in childhood: a PRACTALL consensus report. Allergy 2008, 63:5-34.

14. Amirav I: Aerosol Therapy. Ital J Pediatr 2004, 30:147-156.

15. GINA Report, Global Strategy for Asthma Management and Prevention. http:// www.ginasthma.com. Last access on: 09 February 2012

16. British Thoracic Society, Scottish Intercollegiate Guidelines Network: British Guideline on the management of asthma. http://www.brit-thoracic.org.uk. Last access on: 09

17. National Heart, Lung, and Blood Institute, National Asthma Education and Prevention Program: Expert Panel Report 3. Guidelines for the Diagnosis and Management of Asthma. http://www.nhlbi.nih.gov. Last access on: 09 February 2012

18. Arm JP, Lee TH: Chemical mediators: Leukotrienes and eicosanoids. In Bronchial asthma: mechanisms and therapeutics. Edited by Weiss EB, Stein M. Boston: Little Brown; 1993:112-134.

19. Lewis RA, Austen KF, Soberman RJ: Leukotrienes and other products of the 5-lipoxygenase pathway: biochemistry and relation to pathobiology in human diseases. N Engl J Med 1990, 323:645-655.

20. Arm JP, Lee TH: Sulphidopeptide leukotrienes in asthma. Clin Sci 1993, 84:501-510.

21. Bernstein PR: Chemistry and structure activity relationships of leukotriene receptor antagonists. Am J Respir Crit Care Med 1998, 157:s220-s226.

22. Hakim F, Vilzoni D, Adler A, Livnat G, Tal A, Bentur L: The effect of montelukast on bronchial hyperreactivity in preschool children. Chest 2007, 13:180-186.

23. de Benedictis FM, del Giudice MM, Forenza N, Decimo F, de Benedictis D, Capristo A: Lack of tolerance to the protective effect of montelukast in exercise-induced bronchoconstriction in children. Eur Respir J 2006, 28:291-295

24. Bisgaard H: Role of leukotrienes in asthma pathophysiology. Pediatr Pulmonol 2000, 30:166-176.

25. Corradi M, Zinelli C, Caffarelli C: Exhaled breath biomarkers in asthmatic children. Inflamm Allergy Drug Targets 2007, 6:150-159.

26. Csoma Z, Kharitonov SA, Balint B, Bush A, Wilson NM, Barnes PJ: Increased leukotrienes in exhaled breath condensate in childhood asthma. Am J Respir Crit Care Med 2002, 166:1345-1349.

27. Walia M, Lodha R, Kabra SK: Montelukast in pediatric asthma management. Indian J Pediatr 2006, 73:275-282.

28. Amlani S, Nadarajah T, Mclvor RA: Montelukast for the treatment of asthma in the adult population. Expert Opin Pharmacother 2011, $12: 2119-2128$

29. Cheng H, Leff JA, Amin R, Gertz BJ, De Smet M, Noonan N, Rogers JD, Malbecq W, Meisner D, Somers G: Pharmacokinetics, bioavailability, and safety of montelukast sodium (MK-0476) in healthy males and females. Pharm Res 1996, 13:445-448.

30. Bisgaard $H$, Nielsen KG: Bronchoprotection with a leukotriene receptor antagonist in asthmatic preschool children. Am J Respir Crit Care Med 2000, 162:187-190.
31. Straub DA, Minocchieri S, Moeller A, Hamacher J, Wildhaber JH: The effect of montelukast on exhaled nitric oxide and lung function in asthmatic children 2 to 5 years old. Chest 2005, 127:509-514.

32. Straub DA, Moeller A, Minocchieri S, Hamacher J, Sennhauser FH, Hall GL, Wildhaber $\mathrm{JH}$ : The effect of montelukast on lung function and exhaled nitric oxide in infants with early childhood asthma. Eur Respir J 2005, 25:289-294.

33. Robertson CF, Price D, Henry R, Mellis C, Glasgow N, Fitzgerald D, Lee AJ Turner J, Sant M: Short-course montelukast for intermittent asthma in children: a randomised controlled trial. Am J Respir Crit Care Med 2007, 175:323-329.

34. Knorr B, Franchi LM, Bisgaard H, Vermeulen JH, LeSouef P, Santanello N, Michele TM, Reiss TF, Nguyen HH, Bratton DL: Montelukast, a leukotriene receptor antagonist, for the treatment of persistent asthma in children aged 2 to 5 years. Pediatrics 2001, 108:E48.

35. Davies GM, Dasbach EJ, Santanello NC, Knorr BA, Bratton DL: The effect of montelukast versus usual care on health care resource utilization in children aged 2 to 5 years with asthma. Clin Ther 2004, 26:1895-1904.

36. Bisgaard H, Zielen S, Garcia-Garcia ML, Johnston SL, Gilles L, Menten J, Tozzi CA, Polos P: Montelukast reduces asthma exacerbations in 2- to 5-yearold children with intermittent asthma. Am J Respir Crit Care Med 2005, 171:315-322.

37. Weinberger M: Montelukast for viral respiratory infection-induced exacerbations of asthma. Am J Respir Crit Care Med 2005, 172:783.

38. Szefler SJ, Baker JW, Uryniak T, Goldman M, Silkoff PE: Comparative study of budesonide inhalation suspension and montelukast in young children with mild persistent asthma. J Allergy Clin Immunol 2007, 120:1043-1049.

39. Kooi EM, Schokker S, Marike Boezen H, de Vries TW, Vaessen-Verberne AA, van der Molen T, Duiverman EJ: Fluticasone or montelukast for preschoo children with asthma-like symptoms: Randomized controlled trial. Pulm Pharmacol Ther 2008, 21:798-804

40. Bacharier LB, Phillips BR, Zeiger RS, Szefler SJ, Martinez FD, Lemanske RF Jr, Sorkness CA, Bloomberg GR, Morgan WJ, Paul IM, Guilbert T, Krawiec M, Covar R, Larsen G, Mellon M, Moss MH, Chinchilli VM, Taussig LM, Strunk RC, CARE Network: Episodic use of an inhaled corticosteroid or leukotriene receptor antagonist in preschool children with moderateto-severe intermittent wheezing. J Allergy Clin Immunol 2008, 122:1127-1135

41. Allen-Ramey FC, Markson LE, Riedel AA, Sajjan S, Weiss KB: Patterns of asthma-related health care resource use in children treated with montelukast or fluticasone. Curr Med Res Opin 2006, 22:1453-1461.

42. Smyth AR, Barbato A, Beydon N, Bisgaard H, de Boeck K, Brand P, Bush A, Fauroux B, de Jongste J, Korppi M, O'Callaghan C, Pijnenburg M, Ratjen F, Southern K, Spencer D, Thomson A, Vyas H, Warris A, Merkus PJ: Respiratory medicines for children: current evidence, unlicensed use and research priorities. Eur Respir J 2010, 35:247-265.

43. Bush A: Practice imperfect-treatment for wheezing in preschoolers. $N$ Engl J Med 2009, 360:409-410.

44. Johnston NW, Mandhane PJ, Dai J, Duncan JM, Greene JM, Lambert K, Sears MR: Attenuation of the September epidemic of asthma exacerbations in children: a randomized, controlled trial of montelukast added to usual therapy. Pediatrics 2007, 120:e702-e712.

45. Lenney W, Boner AL, Bont L, Bush A, Carlsen KH, Eber E, Fauroux B, Götz M, Greenough A, Grigg J, Hull J, Kimpen J, Sánchez Luna M, de Benedictis FM: Medicines used in respiratory diseases only seen in children. Eur Respir $J$ 2009, 34:531-551.

46. Da Dalt L, Callegaro S, Carraro S, Andreola B, Corradi M, Baraldi E: Nasal lavage leukotrienes in infants with RSV bronchiolitis. Pediatr Allergy Immunol 2007, 18:100-104

47. Amirav I, Luder AS, Kruger N, Borovitch Y, Babai I, Miron D, Zuker M, Tal G, Mandelberg A: A double-blind, placebocontrolled, randomized trial of montelukast for acute bronchiolitis. Pediatrics 2008, 122:e1249-e1255.

48. Bisgaard H, Flores-Nunez A, Goh A, Azimi P, Halkas A, Malice MP, Marchal JL, Dass SB, Reiss TF, Knorr BA: Study of montelukast for the treatment of respiratory symptoms of post-respiratory syncytial virus bronchiolitis in children. Am J Respir Crit Care Med 2008, 178:854-860.

49. Proesmans M, Sauer K, Govaere E, Raes M, De Bilderling G, De Boeck K: Montelukast does not prevent reactive airway disease in young children hospitalized for RSV bronchiolitis. Acta Paediatr 2009, 98:1830-1834.

50. Bisgaard $\mathrm{H}$ : A randomized trial of montelukast in respiratory syncytial virus postbronchiolitis. Am J Respir Crit Care Med 2003, 167:379-383. 
51. Kim CK, Choi J, Kim HB, Callaway Z, Shin BM, Kim JT, Fujisawa T, Koh YYA: Randomized intervention of montelukast for post-bronchiolitis: effect on eosinophil degranulation. J Pediatr 2010, 156:749-754

52. Harmanci K, Bakirtas A, Turktas I, Degim T: Oral montelukast treatment of preschool-aged children with acute asthma. Ann Allergy Asthma Immunol 2006, 96:731-735.

53. Kozer E, Lotem Z, Elgarushe M, Torgovicky R, Cohen R, Cohen HA, Berkovitch M: RCT of montelukast as prophylaxis for upper respiratory tract infections in children. Pediatrics 2012, 129:285-290.

54. Bisgaard H, Skoner D, Boza ML, Tozzi CA, Newcomb K, Reiss TF, Knorr B, Noonan G: Safety and tolerability of montelukast in placebo-controlled pediatric studies and their open-label extensions. Pediatr Pulmonol 2009, 44:568-579.

55. Baiardi P, Ceci A, Felisi M, Cantarutti L, Girotto S, Sturkenboom M, Baraldi E: In-label and off-label use of respiratory drugs in the Italian paediatric population. Acta Paediatr 2010, 99:544-549.

56. Forrester MB: Pediatric montelukast ingestions reported to Texas poison control centers, 2000-2005. J Toxicol Environ Health A 2007, 70:1792-1797.

57. Cobb DB, Abbott CL, Watson WA, Fernández MC: High-dose montelukast exposures in a 3-year-old and a 5-year-old child. Vet Hum Toxicol 2002, 44:91-92.

58. Churg J, Strauss L: Allergic granulomatosis, allergic angitis, and periarteritis nodosa. Am J Pathol 1951, 27:277-301.

59. Nathani N, Little MA, Kunst H, Wilson D, Thickett DR: Churg-Strauss syndrome and leukotriene antagonist use: a respiratory perspective. Thorax 2008, 63:883-888.

60. Philip G, Hustad C, Noonan G, Malice MP, Ezekowitz A, Reiss TF, Knorr B: Reports of suicidality in clinical trials of montelukast. J Allergy Clin Immunol 2009, 124:691-696.

61. Simons FE, Villa JR, Lee BW, Teper AM, Lyttle B, Aristizabal G, Laessig W, Schuster A, Perez-Frias J, Sekerel BE, Menten J, Leff JA: Montelukast added to budesonide in children with persistent asthma: a randomized, double-blind, crossover study. J Pediatr 2001, 138:694-698

62. Brand PL, Baraldi E, Bisgaard H, Boner AL, Castro-Rodriguez JA, Custovic A, de Blic J, de Jongste JC, Eber E, Everard ML, Frey U, Gappa M, Garcia-Marcos L, Grigg J, Lenney W, Le Souëf P, McKenzie S, Merkus PJ, Midulla F, Paton JY, Piacentini G, Pohunek P, Rossi GA, Seddon P, Silverman M, Sly PD, Stick S, Valiulis A, van Aalderen WM, Wildhaber JH, et al: Definition, assessment and treatment of wheezing disorders in preschool children: an evidence-based approach. Eur Respir J 2008, 32:1096-1110.

63. Schultz A, Payne D: Danger of using an unreliable classification system for preschool wheeze. Eur Respir J 2009, 33:944-945.

64. Schultz A, Devadason SG, Savenije OE, Sly PD, Le Souëf PN, Brand PL: The transient value of classifying preschool wheeze into episodic viral wheeze and multiple trigger wheeze. Acta Paediatr 2010, 99:56-60.

65. Baraldi E, Donegà S, Carraro S, Farina M, Barbato A, Cutrone C Tracheobronchomalacia in wheezing young children poorly responsive to asthma therapy. Allergy 2010, 65:1064-1065.

66. Bacharier LB: Viral-induced wheezing episodes in preschool children: approaches to therapy. Curr Opin Pulm Med 2010, 16:31-35.

67. Philip G, Pedinoff A, Vandormael K, Tymofyeyev Y, Smugar SS, Reiss TF, Korenblat PE: A phase I randomized, placebo-controlled, dose-exploration study of single-dose inhaled montelukast in patients with chronic asthma. J Asthma 2010, 47:1078-1084.

\section{Submit your next manuscript to BioMed Central and take full advantage of:}

- Convenient online submission

- Thorough peer review

- No space constraints or color figure charges

- Immediate publication on acceptance

- Inclusion in PubMed, CAS, Scopus and Google Scholar

- Research which is freely available for redistribution

Submit your manuscript at www.biomedcentral.com/submit
C Biomed Central 